\title{
Phosphate Energy Metabolism During Domoic Acid-Induced Seizures
}

\author{
*†Garnette R. Sutherland, "Brian D. Ross, *†Howard Lesiuk, ††James Peeling, \\ $\S$ Neelan Pillay, and $†$ Carl Pinsky
}

\author{
${ }^{*}$ Departments of Surgery (Neurosurgery), tPharmacology and Therapeutics, $\Varangle$ Radiology and $\$$ Medicine \\ (Neurology), The University of Manitoba, Winnipeg Canada; and "Departments of Radiology and Biological \\ Chemistry, University of Michigan, Ann Arbor, Michigan, U.S.A.
}

\begin{abstract}
Summary: The effect of domoic acid-induced seizure activity on energy metabolism and on brain $\mathrm{pH}$ in mice was studied by continuous EEG recording and in vivo ${ }^{31} \mathrm{P}$ nuclear magnetic resonance (NMR) spectroscopy. Mice were divided into ventilated $(n=6)$ and nonventilated $(n$ $=7$ ) groups. Baseline EEG was 0.1-mV amplitude with frequence of $>30-\mathrm{Hz}$ and of $4-5 \mathrm{~Hz}$. After intraperitoneal (i.p.) administration of domoic acid $(6 \mathrm{mg} / \mathrm{kg})$, electrographic spikes appeared at increasing frequency, progressing to high-amplitude $(0.1-0.8 \mathrm{mV})$ continuous seizure activity (status epilepticus). In ventilated mice, the $\left[{ }^{31} \mathrm{P}\right] \mathrm{NMR}$ spectra showed that high-energy phosphate levels and tissue $\mathrm{pH}$ did not change after domoic acid administration or during the intervals of spiking or status epilepticus. Nonventilated mice showed periods of EEG suppression accompanied by decreases in the levels of
\end{abstract}

high-energy phosphate metabolites and in $\mathrm{pH}$, corresponding to episodic respiratory suppression during the spiking interval. In all animals, status epilepticus was followed by a marked decrease in EEG amplitude that progressed rapidly to isoelectric silence. [ [ $\left.{ }^{31} \mathrm{P}\right] \mathrm{NMR}$ spectra obtained after this were indicative of total energy failure and tissue acidosis. In a separate group of ventilated mice $(n=4)$, domoic acid-induced status epilepticus was accompanied initially by an increase in mean arterial blood pressure (MAP) that slowly returned to baseline level. Isoelectric silence was accompanied by a decrease in MAP to $75 \pm 8 \mathrm{~mm} \mathrm{Hg}$. These experiments suggest that domoic acid-induced seizures are not accompanied by an increase in substrate demand that exceeds supply. Key Words: Domoic acid_- ${ }^{31} \mathrm{P}$ Spectroscopy-Status epilepticus-Neurologic models.
Excessive neuronal excitation has been implicated as an important cause of neuronal injury in such neurologic disorders as cerebral ischemia, hypoglycemia, and epilepsy (Auer and Siesjö, 1988; Meldrum, 1989), although the mechanisms causing cell damage are not completely understood (Raichle, 1983; Seisjö, 1987). In models of seizures induced by bicuculline (BIC) (Folbergrova et al., 1981; McCandless et al., 1986), pentylenetetrazol (PTZ) (Duffy et al., 1975; Ingvar et al., 1984); fluorothyl (Duffy et al., 1975; Folbergrova et al., 1985), and electroshock (Duffy et al., 1975; Young et al., 1987), seizure activity is accompanied within minutes by a modest decrease in cerebral phosphocreatine ( $\mathrm{PCr}$ ), ATP, and $\mathrm{pH}$, suggesting that during a seizure, cerebral substrate demand exceeds supply

Received July 1991; revision accepted February 1993.

Address correspondence and reprint requests to Dr. G. Sutherland at Department of Clinical Neurosciences, Division of Neurosurgery, Foothills Hospital, 1403-29 St. N.W., Calgary, Alberta T2N 2T9, Canada. and implicating cellular energy failure as one possible etiologic factor for irreversible neuronal damage associated with these status epilepticus models. Metabolic changes accompanying seizures induced by direct excitatory (glutamate) receptor agonists have been less well established. In the case of the kainate receptor, intrastitial injections of kainic acid (KA) caused selective neuronal damage and progressive decreases in striatal levels of PCr and ATP in mice (Retz and Coyle, 1982). Systemic administration of KA has been reported to cause regional acidosis and decreases in ATP levels in rat brain (Kobayashi et al., 1990), although the changes were not quantified. The relation between changes in metabolism and EEG activity caused by activation of the kainate receptor has not been established.

Domoic acid, which has been shown to result in seizures and neuronal injury in both animal models (Iverson et al., 1989; Dakshinamurti, et al., 1991; Strain and Tasker, 1991; Tasker et al., 1991) and humans (Quilliam and Wright, 1989; Stewart et al., 
1990; Teitlebaum et al., 1990) has a three fold higher affinity than KA for the kainate receptor (Slevin et al., 1983; Debonnel et al., 1989; Stewart et al., 1990). In this study, simultaneous ${ }^{31} \mathrm{P}$ nuclear magnetic resonance (NMR) spectroscopy and EEG measurements were performed to correlate cerebral energy status with brain electrical activity in a mouse model of status epilepticus induced by domoic acid.

\section{METHODS AND MATERIALS}

\section{Animal preparation}

Seventeen female Swiss-Webster mice (Charles River) weighing $25-27 \mathrm{~g}$ were used. The animals were anesthetized with diazepam $(15 \mathrm{mg} / \mathrm{kg}$ intraperitoneally, i.p.), the cranium was exposed through a midline scalp incision, and a $1-\mathrm{cm}$ diameter single-turn circular surface coil was placed on the cranium so that NMR spectra could be obtained from the entire forebrain. Platinum cortical electrodes were inserted through small burr holes drilled lateral to the surface coil and $1.5 \mathrm{~mm}$ posterior to the coronal suture. The electrodes and surface coil were fixed to the cranium with $n$-butyl-2cyanoacrylate. A tracheostomy was performed on 11 mice, and the animals were ventilated to main- tain normal arterial blood gases $\left(\mathrm{PaCO}_{2} \sim 38 \mathrm{~mm} \mathrm{Hg}\right.$ and $\mathrm{PaO}_{2} \sim 100 \mathrm{~mm} \mathrm{Hg}$ ). In 4 of these mice, a catheter was inserted in the descending aorta to monitor blood pressure (BP). Ventilatory settings were established from a series of 8 mice that were killed to establish a correlation between blood gases and ventilatory volume and rate.

\section{$\left[{ }^{31} \mathrm{P}\right]$ NMR spectroscopy}

The NMR experiments were conducted with an 8.45-T Nicolet 360 vertical bore spectrometer. The surface coil was double-tuned to ${ }^{1} \mathrm{H}(360.99 \mathrm{MHz}$, for shimming purposes) and ${ }^{31} \mathrm{P}(146.13 \mathrm{MHz})$. A $105^{\circ}$ flip angle at the coil center $(10 \mu$ s pulse) was used with a repetition time of $4.113 \mathrm{~s}$ and 20 scans per spectrum so that spectra were generated in blocks of $90 \mathrm{~s}$ (Fig. 1). Calculated spectra were fitted to experimental spectra by an analogue deconvolution routine that gave peak positions and integrated intensities. All peak fitting was performed with the investigator blinded to origin of the spectrum.

\section{Drug administration}

After baseline EEG and [ $\left.{ }^{31} \mathrm{P}\right]$ NMR spectra were acquired, domoic acid (Sigma; $6 \mathrm{mg} / \mathrm{kg}$ i.p.) was administered. The experimental animals were then followed with EEG and $\left[{ }^{31} \mathrm{P}\right] \mathrm{NMR}$ spectroscopy until isoelectric silence occurred.

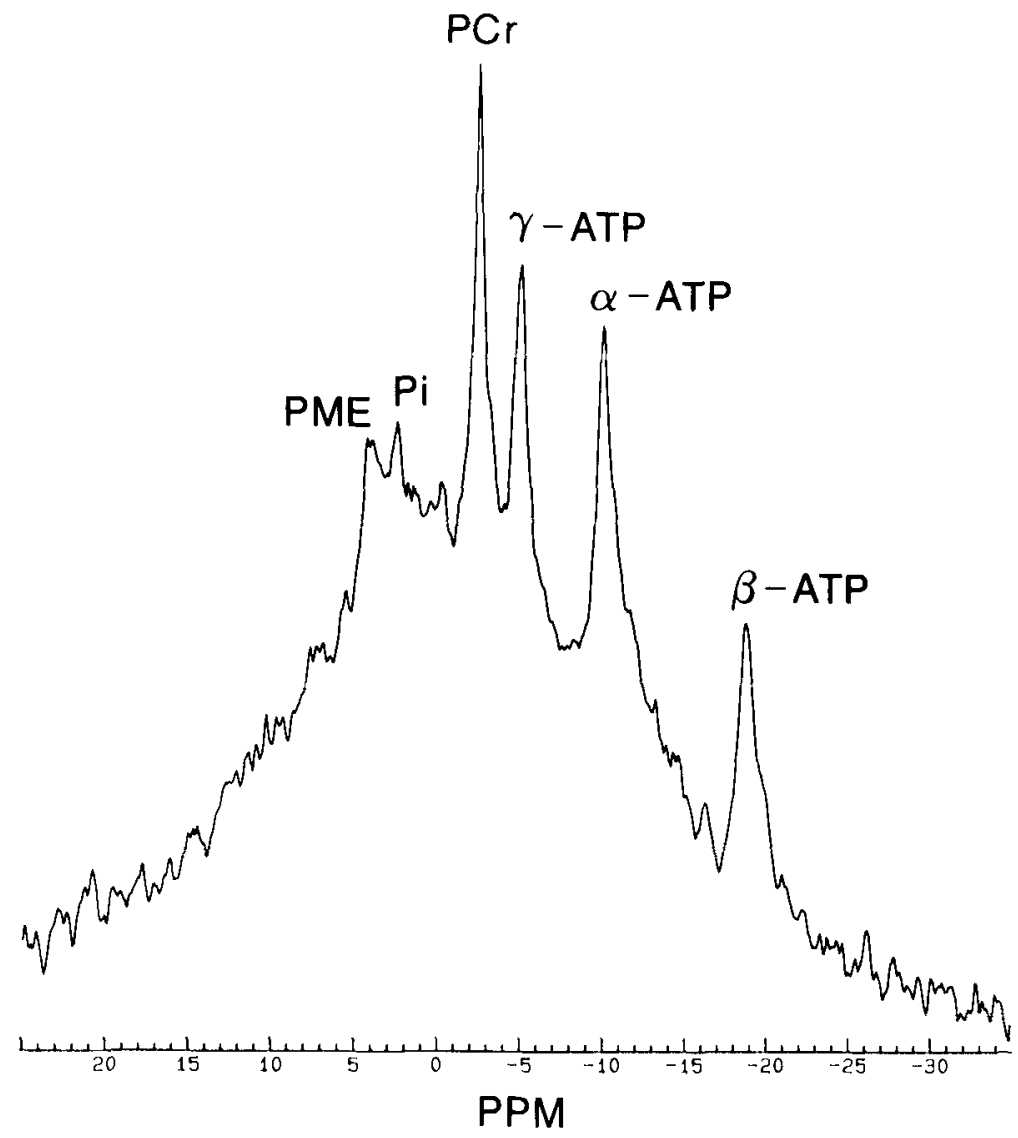

FIG. 1. ${ }^{31} \mathrm{P}$ Nuclear magnetic resonance spectrum of mouse brain before injection of domoic acid. Peak assignments as labeled: PME, phosphomonoesters; $\mathrm{Pi}$, inorganic phosphate; $\mathrm{PCr}$, phosphocreatine; $\gamma$-ATP, $\alpha$-ATP, and $\beta$, ATP- $\gamma$, $\alpha$, and $\beta$ phosphorous of ATP. 


\section{RESULTS}

In nonventilated mice $(n=6)$, baseline EEG had frequencies of $4-5 \mathrm{~Hz}$ and $>30 \mathrm{~Hz}$, both of $0.1-0.2$ $\mathrm{mV}$ amplitude (Fig. 2). One to $5 \mathrm{~min}$ after domoic acid injection, repetitive low-amplitude (0.1-0.2 $\mathrm{mV})$ and high-amplitude $(0.7-0.8 \mathrm{mV})$ spikes appeared at variable frequency. Bursts of highamplitude 2-3 s polyspikes also occurred, along with brief periods of EEG suppression lasting 4-24 $\mathrm{s}$. This continued for $10-35 \mathrm{~min}$, followed by $9-18$ min of high-amplitude $(0.7-0.8 \mathrm{mV})$ continuous spikes (status epilepticus), followed in turn by a decrease in EEG amplitude, progressing in 1-2 min to isoelectric silence, after which EEG activity did not resume. Baseline $\left[{ }^{31} \mathrm{P}\right] \mathrm{NMR}$ spectra showed the characteristic high-energy phosphate peaks of $\mathrm{PCr}$ and of the $\alpha, \beta$, and $\gamma$ phosphate groups of ATP superimposed on a broad background peak owing to immobile phosphates (Fig. 1). A baseline intracellular pH of $7.12 \pm 0.03$ (mean \pm SEM) was calculated from the chemical shift of inorganic phosphate (Pi) relative to PCr. The NMR spectra obtained during the intervals of domoic acid-induced spikes or polyspikes were unchanged (Fig. 2). Spectra acquired during the intervals of EEG suppression had decreased amplitudes of high-energy phosphate peaks and increased $\mathrm{Pi}$, however, and showed that tissue $\mathrm{pH}$ decreased slightly. These changes were reversed in spectra acquired after resumption of EEG activity. Notably, spectra obtained during the interval of status epilepticus were identical to those acquired before domoic acid administration. In successive spectra obtained after the terminal decrease in EEG amplitude, however, the high-energy phosphate peaks decreased rapidly, the $\mathrm{Pi}$ peak increased in intensity, and the intracellular $\mathrm{pH}$ decreased to $6.45 \pm 0.02$ (Figs. 2 and 3). Spectra obtained after isoelectric silence had no peaks from $\mathrm{PCr}$ or ATP but an intense Pi peak.

Similar phenomena were noted in ventilated mice $(\mathrm{n}=7)$. EEG spikes appeared 4-6 min after domoic acid administration and continued with variable frequency for 24-45 $\mathrm{min}$, followed by 15-21 $\mathrm{min}$ of status epilepticus. The $\left[{ }^{31} \mathrm{P}\right] \mathrm{NMR}$ spectra remained unchanged throughout these periods of seizure activity, and no episodes of EEG suppression occurred (Fig. 4). As with nonventilated mice, highamplitude $(0.7-0.8 \mathrm{mV})$ status epilepticus ended with a decrease in EEG amplitude. $\left[{ }^{31} \mathrm{P}\right] \mathrm{NMR}$ spectra obtained after this showed a decrease in the intensity of high-energy phosphate metabolite peaks, an increase in the Pi peak, and a decrease in intracellular $\mathrm{pH}$ to $6.53 \pm 0.04$ (Fig. 5).

In the 4 mice in which systemic arterial BP was
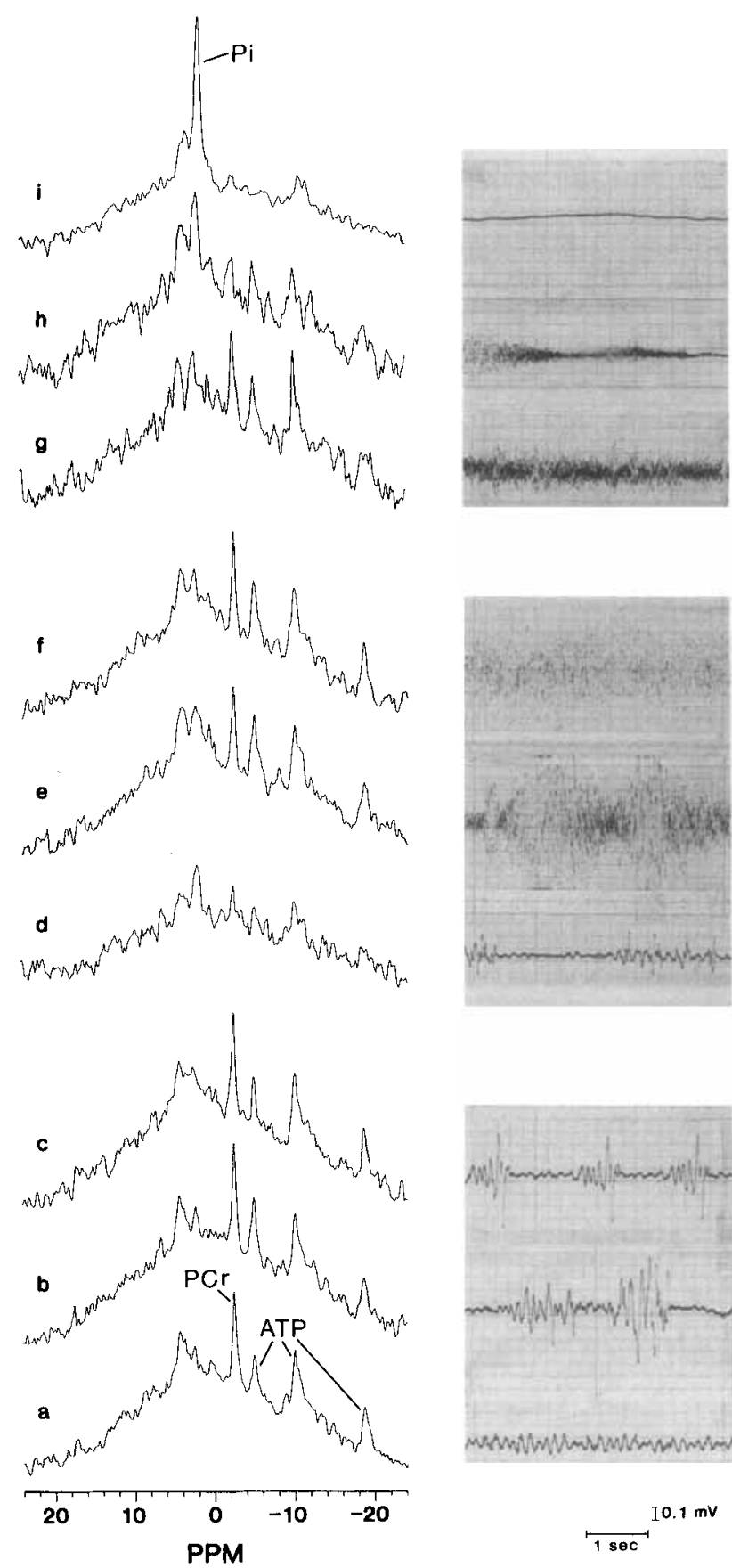

FIG. 2. ${ }^{31} \mathrm{P}$ Nuclear magnetic resonance (NMR) spectra and EEG recordings from a nonventilated mouse obtained before domoic acid administration (a) and at increasing time intervals after domoic acid administration $(b-i)$ : $b$ and $c$ EEG recordings show representative spikes and polyspikes appearing at increasing frequency after domoic acid administration and typical $\left[{ }^{31} \mathrm{P}\right]$ NMR spectra obtained during this interval; $d$ is an example of an episode of EEG suppression, accompanied by a decrease in levels of high-energy phosphates and a decrease in $\mathrm{pH}$. Progression of EEG spikes to high-amplitude continuous $(0.7-0.8 \mathrm{mV}$ ) seizure activity (status epilepticus) $(\mathrm{e}-\mathrm{g})$, together with typical [ ${ }^{31} \mathrm{PJNMA}$ spectra recording during this time, showing normal phosphate metabolite levels and $\mathrm{pH}$. Rapid onset of isoelectric silence is shown in $\mathrm{h}$ and $i$, and [ ${ }^{31}$ P]NMR spectra recorded during this time showed progressing energy failure. 


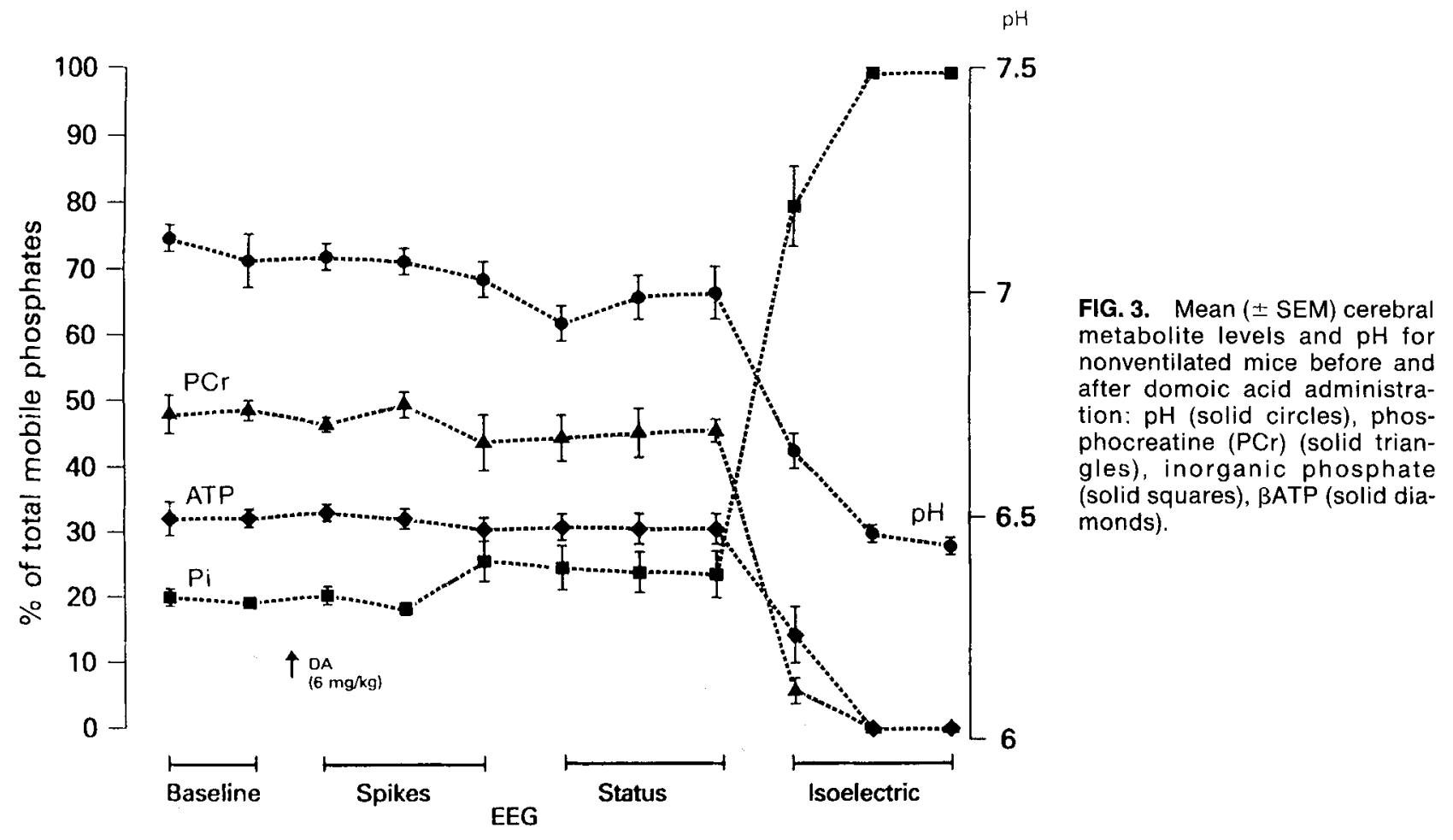

monitored, mean MAP initially increased during status epilepticus from $105 \pm 3$ to $130 \pm 9 \mathrm{~mm} \mathrm{Hg}$ (mean \pm SEM) and then decreased slowly to values prestatus epilepticus. Coincident with the change from high-amplitude status epilepticus to EEG silence, the heart rate (HR) decreased and MAP decreased to $75 \pm 8 \mathrm{~mm} \mathrm{Hg}$.

\section{DISCUSSION}

The high affinity of domoate for the kainate receptor (Zaczek and Coyle, 1982; Debonnel et al., 1989); potentiates rapid and repetitive neuronal firing, expressed in our experimental animals as continuous EEG spiking activity. The dosage of diazepam (DZP) used in the present study produced continuous analgesia and mild sedation. The anticonvulsant properties of DZP may have suppressed epileptiform activity or the metabolic response to status epilepticus. The observed epileptiform activity progressing rapidly to status epilepticus suggests that this effect was minimal and underscores the clinical difficulty in treating seizures associated with domoic acid ingestion (Teitlebaum et al., 1990).

In nonventilated mice, the episodes of EEG suppression, during which levels of high-energy phosphate metabolites and tissue $\mathrm{pH}$ decreased, probably reflect impaired oxygen delivery through respiratory suppression and the accompanying anaerobic metabolism of glucose. Such episodes did not occur in ventilated mice. Changes in $\left[{ }^{31} \mathrm{P}\right] \mathrm{NMR}$ spectra provide a sensitive means of observing the adequacy of substrate supply, with decreased cerebral PCr and/or ATP levels rapidly becoming apparent when glucose or oxygen is insufficient (Prichard and Shulman, 1986; Bolas et al., 1988). In ventilated mice, the normal levels of phosphate metabolites and tissue $\mathrm{pH}$ before onset of status epilepticus spiking activity and throughout the $30-50 \mathrm{~min}$ of continuous seizure activity indicate that the supply of both glucose and oxygen was adequate to meet demand, and that mitochondrial function remains capable of maintaining normal cerebral energy status. This is true of seizures initiated by BIC (Folbergrova et al., 1981; Petroff et al., 1984; McCandless et al., 1986), PTZ (Ingvar et al., 1984), or fluorothyl (Folbergrova et al., 1985), in which PCr levels decrease within minutes of onset of status epilepticus, and ATP levels decline somewhat later. This suggests that in these models substrate demand exceeds supply in the setting of continuous seizure activity and may contribute to neuronal injury. In rats, systemic administration of KA does not result in decreased levels of cerebral ATP until 60 min after administration; the decreases then appear to be slight and restricted to a few selective brain regions (Kobayashi et al., 1990). The correlation of these changes with EEG activity was not described. In the present study, maintenance of cerebral energy status throughout the EEG-defined spiking and continuous seizure activity suggests 

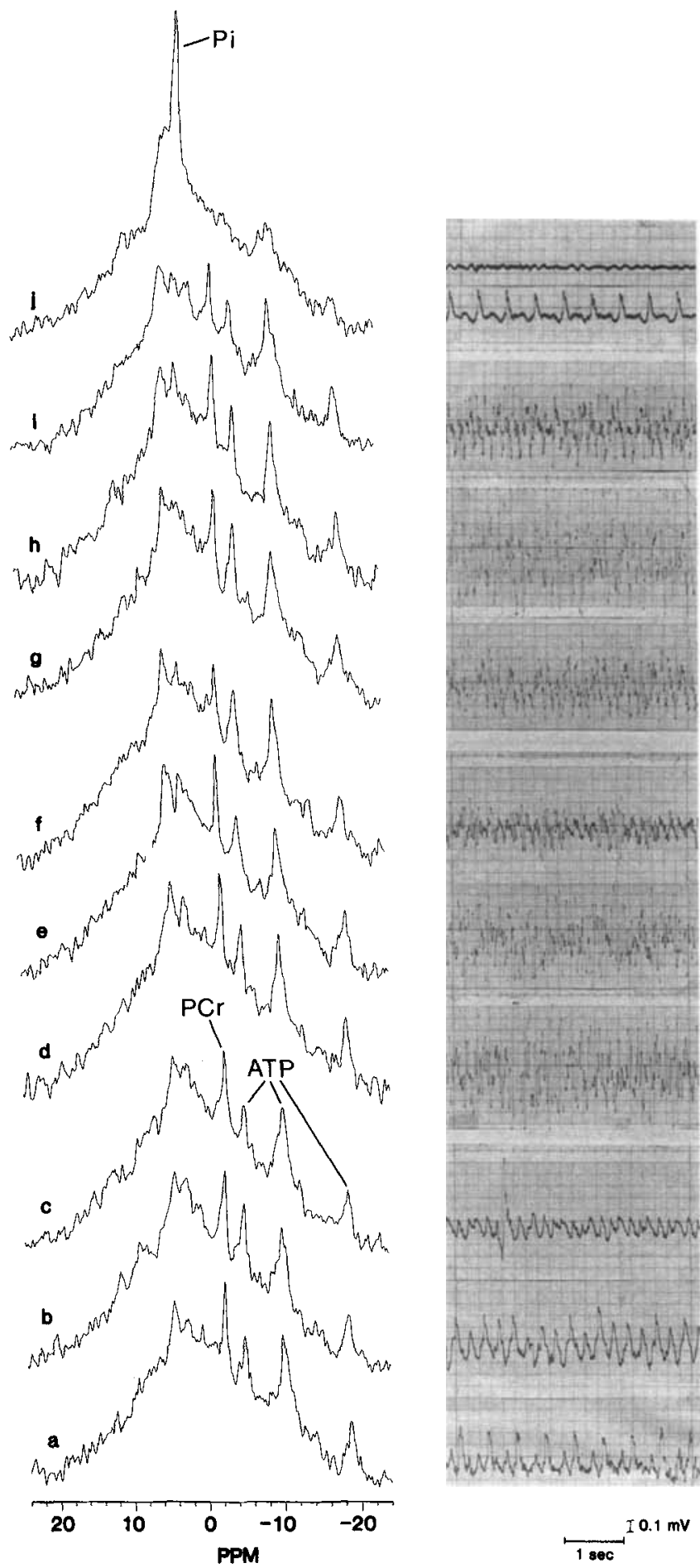

FIG. 4. ${ }^{31} \mathrm{P}$ Nuclear magnetic resonance (NMR) spectra and EEG recordings from a ventilated mouse obtained before domoic acid administration (a) and at progressively increasing intervals after domoic acid administration (b-j). Domoic acid administration resulted at first in increasingly frequent lowand high-amplitude spikes (b-d). This progressed to status epilepticus $(e-h)$. These changes were not accompanied by changes in the $\left[{ }^{31} \mathrm{P}\right]$ NMR spectra. Similar to nonventilated mice, onset of isoelectric silence ( $i$ and $j)$, was accompanied by energy failure. In j, the two EEG traces show the effect of the ventilator. that substrate supply is maintained even in the setting of increased demand defined by the increased EEG activity.

Status epilepticus ends with EEG silence, and only those NMR spectra obtained after this silence complete cerebral energy failure, suggesting that the toxicity of domoic acid does not result simply from induction of sustained seizures, with energy demand ultimately exceeding supply. Indeed, in both ventilated and nonventilated mice, the terminal decrease in $\mathrm{pH}$ must originate from anaerobic metabolism of glucose, indicating that substrate supply, at least of glucose, was present at the time of energy and electrical failure. The toxicity of domoic acid may originate from such factors as membrane dysfunction, with opening of chloride, sodium and calcium channels in both neuronal and glial populations (Farber, 1981; Lothman and Collins, 1981; Coyle, 1983; MacDermott et al., 1986; Murphy and Miller, 1989; Seisjö and Bengtsson, 1989; Coyle et al., 1991). In vitro, where neuronal energy demands are low, such metabolic and excitotoxin-induced conditions have been shown to lead rapidly ( $<30 \mathrm{~min}$ ) to cell death (Novelli et al., 1988). Excitotoxins have also been shown to produce a steady depolarization, resulting in an influx of chloride and followed by movement of cations into the cell, in turn resulting in water entry and cell lysis (Rothman, 1985; Coyle et al., 1991).

In nonanesthetized mice, domoate at a dosage similar to that used in the present study results in damage to circumventricular organs lacking a blood-brain barrier (Bruni et al., 1991). Such findings are in keeping with autonomic disturbances (gastrointestinal, salivation, cardiovascular vomiting) associated with domoate toxicity (Tryphonas and Iverson, 1990) and may explain the sudden decrease in systemic BP observed in the present study. MAP of $75 \mathrm{~mm} \mathrm{Hg}$ is sufficient to maintain normal cerebral perfusion but may be insufficient to maintain the increased metabolic demand of sustained status epilepticus. The rapid energy and electrical failure is not consistent with progressing cerebral edema that eventually results in decreased cerebral blood flow because of increased intracranial pressure. Such an occurrence probably would have been associated with systemic hypertension (Forster, 1943) and possibly a short interval of isoelectric silence preceding energy failure (Astrup et al., 1981), whereas in the present study simultaneous energy and electrical failure occurred together with stable BP preceding the terminal event.

Acknowledgment: This work was supported by grants from the Manitoba Health Research Council, The Cana- 
FIG. 5. Mean ( \pm SEM) cerebral metabolite levels and $\mathrm{pH}$ for ventilated mice before and after domoic acid administration. $\mathrm{pH}$ (solid circles), phosphocreatine (PCr) (solid triangles), inorganic phosphate (solid squares), $\beta A T P$ (solid diamonds).

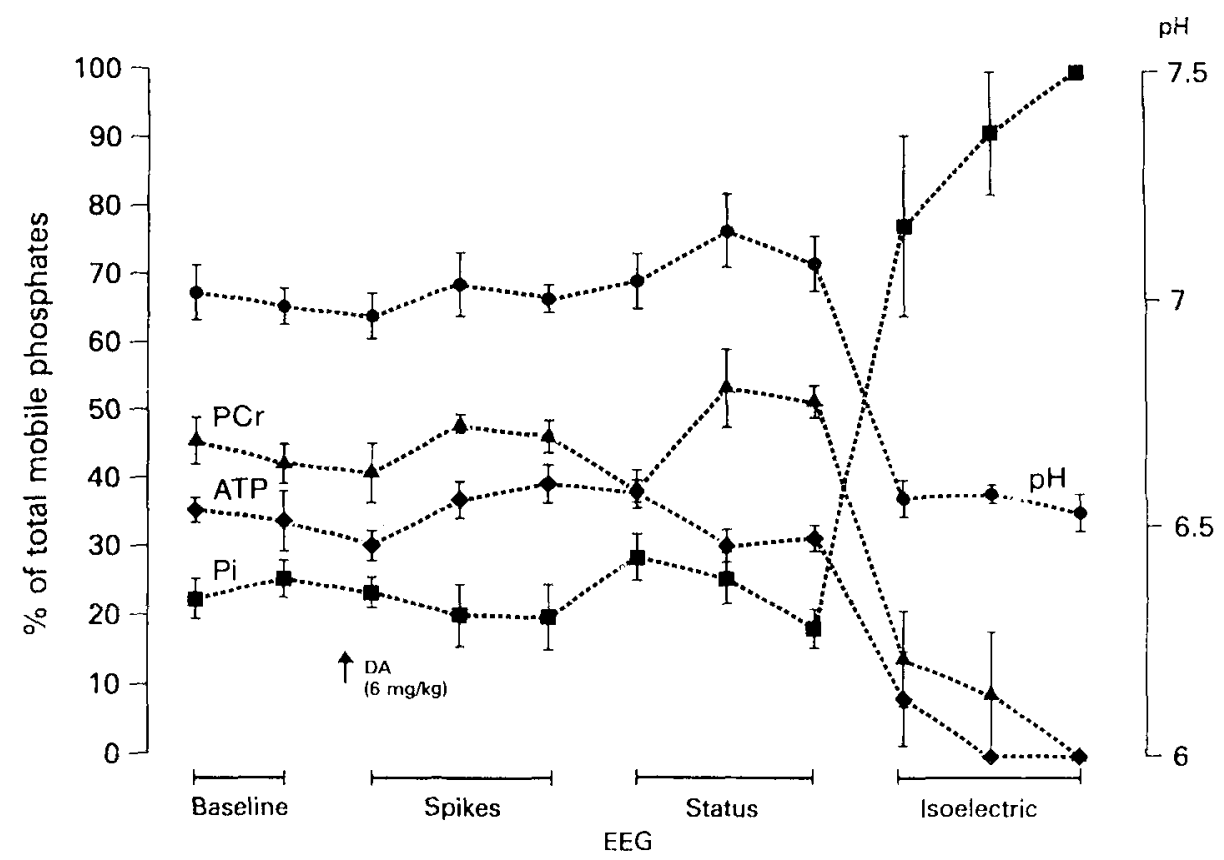

dian Heart and Stroke Foundation, Health and Welfare Canada/NHRDP, and Medical Research Council of Canada. We thank Dr. Kamil Ugurbil at the Gray Freshwater Biological Institute, Navarre, MN, U.S.A., for the use of his experimental laboratory and technical staff.

\section{REFERENCES}

Astrup J, Siesjö BK, Symon L. Thresholds in cerebral ischemia-the ischemic penumbra. Stroke 1981;12:723-5.

Auer RN, Siesjö BK. Biological differences between ischemia, hypoglycemia, and epilepsy. Ann Neurol 1988;24:699-707.

Bolas NM, Rajagopalan B, Mitsumori F, Radda GK. Metabolic changes during experimental cerebral ischemia in hyperglycemic rats, observed by ${ }^{31} \mathrm{P}$ and ${ }^{1} \mathrm{H}$ magnetic resonance spectroscopy. Stroke 1988;19:608-14.

Bruni JE, Bose R, Pinsky C, Glavin G. Circumventricular organ origin of domoic acid-induced neuropathology and toxicology. Brain Res Bull 1991;26:419-24.

Coyle JT. Neurotoxic action of kainic acid. $J$ Neurochem 1983; 41:1-11.

Coyle JT, Murphy TH, Puttfarcken PS, Lyons EW, Vornov JJ. The nonexcitatory mechanisms of glutamate induced neurotoxicity. Epilepsy Res 1991;10:41-8.

Dakshinamurti K, Sharma SK, Sundaram M. Domoic acid induced seizure activity in rats. Neurosci Lett 1991;27:193-7.

Debonnel G, Beauchesne L, DeMontigny C. Domoic acid, the alleged "mussel toxin," might produce the neurotoxic effect through kainate receptor activation: an electrophysiological study in the rat dorsal hippocampus. Can J Physiol Pharmacol 1989;67:29-33.

Duffy TE, Howse DC, Plum F. Cerebral energy metabolism during experimental status epilepticus. J Neurochem 1975;24: 925-34.

Farber JL. The role of calcium in cell death. Life Sci 1981;29: 1289-95.

Folbergrova J, Ingvar M, Nevander G, Siesjö BK. Cerebral metabolic changes during and following fluorothyl-induced seizures in ventilated rats. $J$ Neurochem $1985 ; 44: 1419-26$.

Folbergrova J, Ingvar M, Siesjö BK. Metabolic changes in cerebral cortex, hippocampus, and cerebellum during sustained bicuculline-induced seizures. $J$ Neurochem 1981;37:1228-38.

Forster FM. The role of the brainstem in arterial hypertension subsequent to intracranial hypertension. Am J Physiol 1943; 139:347-50.

Ingvar M, Soderfeldt B, Folbergrova J, Kalimo H, Olsson Y, Seisjö BK. Metabolic, circulatory, and structural alterations in the rat brain induced by sustained pentylenetetrazole seizures. Epilepsia 1984;25:191-204.

Iverson F, Truelove J, Nera E, Tryphonas L, Campbell J, Lok E. Domoic acid poisoning and mussel-associated intoxication: preliminary investigations into the response of mice and rats to toxic mussel extract. Food Chem Toxicol 1989;27:37784.

Kobayashi S, Kikuchi H, Ishikawa M, Hashimoto K. Regional changes of tissue $\mathrm{pH}$ and ATP content in rat brain following systemic administration of kainic acid. Brain Res 1990;514: $352-4$.

Lothman EW, Collins RC. Kainic acid induced limbic seizures: metabolic behavioral, electroencephalographic and neuropathological correlates. Brain Res 1981;218:299-318.

MacDermott AB, Mayer ML, Westbrook GL, Smith SJ, Baker JL. NMDA-receptor activation increases cytoplasmic calcium concentration in cultured spinal cord neurons. Nature 1986;321:519-22.

McCandless DW, DeFrance JF, Dworsky S, Presley-Zimmer E. Status epilepticus-induced changes in primate cortical energy metabolism. Am J Physiol 1986;251:C774-9.

Meldrum B. Excitotoxicity in ischemia: an overview. In: Ginsberg MD, Dietrich WD, eds. Cerebral vascular diseases. New York: Raven Press, 1989;47-60.

Murphy SN, Miler RJ. Regulation of $\mathrm{Ca}^{++}$influx into striatal neurons by kainic acid. J Pharmacol Exp Ther 1989;249:184 93.

Novelli A, Reilly JA, Lysko PG, et al. Glutamate becomes neurotoxic via the $N$-methyl-D-aspartate receptor when intracellular energy levels are reduced. Brain Res 1988;451:205-12.

Petroff OAC, Prichard JW, Behar KL, et al. In vivo phosphorous nuclear magnetic resonance spectroscopy in status epilepticus. Ann Neurol 1984;16:169-77.

Prichard JW, Shulman RG. NMR spectroscopy of brain metabolism in vivo. Annu Rev Neurosci 1986;9:61-85.

Petroff OAC, Prichard JW, Ogino T, Avison M, Alger JR, Shulman RG. Combined ${ }^{1} \mathrm{H}$ and ${ }^{31} \mathrm{P}$ nuclear magnetic resonance spectroscopic studies of bicuculline-induced seizures in vivo. Ann Neurol 1986;20:185-93. 
Quilliam MA, Wright JLC. The amnesic shellfish poisoning mystery. Anal Chem 1989;61:1053A-9A.

Raichle ME. The pathophysiology of brain ischemia. Ann Neurol 1983;13:2-10.

Retz KC, Coyle JT. Effects of kainic acid on high-energy metabolites in the mouse striatum. $J$ Neurochem 1982;38:196203.

Rothman SM. The neurotoxicity of excitatory amino acids is produced by passive chloride influx. $J$ Neurosci 1985;5: $1483-9$.

Seisjö BK. Cell damage in the brain: a speculative synthesis. $J$ Cereb Blood Flow Metab 1987;1:155-86.

Seisjö BK, Bengtsson F. Calcium fluxes, calcium antagonists, and calcium-related pathology in brain ischemia, hypoglycemia, and spreading depression: a clarifying hypothesis. $J$ Cereb Blood Flow Metab 1989;9:127-40.

Slevin JT, Collins JF, Coyle JT: Analogue interactions with the brain receptor labeled by $\left[{ }^{3} \mathrm{H}\right]$ kainic acid. Brain Res 1983 ; 265:169-72.

Stewart GR, Zorumski CF, Price AT, Olney JW. Domoic acid: a dementia-inducing excitotoxic food poison with kainic acid receptor specificity. Exp Neurol 1990;110:121-38.

Strain SM, Tasker RAR. Hippocampal damage produced by systemic injections of domoic acid in mice. Neuroscience 1991; $44: 343-52$.

Tasker RAR, Connell BJ, Strain SM. Pharmacology of systemically administered domoic acid in mice. Can J Physiol Pharmacol $1991 ; 69: 378-82$.

Teitlebaum JS, Zatorre RJ, Carpenter S, et al. Neurologic sequelae of domoic acid intoxication due to ingestion of mussels from Prince Edward Island. N Engl J Med 1990;322: $1781-7$.

Tryphonas L, Iverson F. Neuropathology of excitatory neurotoxins: the domoic acid model. Toxicol Pathol 1990;18:165-9.

Young RSK, Cowan B, Briggs RW. Brain metabolism after electroshock seizure in the neonatal dog: a $\left[{ }^{31} \mathrm{P}\right]$ NMR study. Brain Res Bull 1987;18:261-3.

Zaczek R, Coyle JT. Excitatory amino acid analogues: neurotoxicity and seizures. Neuropharmacology 1982;21:15-26.

\section{RÉSUMÉ}

L'effet de l'activité critique induite par acide domoïque sur le métabolisme énergétique sur le $\mathrm{PH}$ cérébral a été étudié chez la souris au moyen d'enregistrements EEG continus et d'une spectroscopie en résonance magnétique nucléaire utilisant le ${ }^{31} \mathrm{P}$ in vivo. Les souris ont été réparties en groupes ventilés $(n=6)$ et non ventilés $(n=7)$. L'EEG de base avait une amplitude de 0.1 $\mathrm{mV}$ avec des fréquences supérieurs à $30 \mathrm{~Hz}$ et de 4 à $5 \mathrm{~Hz}$. Après administration intrapéritonéale d'acide domoïque $(6 \mathrm{mg} / \mathrm{kg})$, des pointes sont apparues sur l'EEG avec une fréquence croissante, progressant vers une activité critique continue de haute amplitude $(0.1$ à $0.8 \mathrm{mV})$ (état de mal épileptique). Chez les souris ventilées, les spectres IRM ${ }^{31} \mathrm{P}$ ont montré que les concentrations de phosphates de haute énergie et le $\mathrm{PH}$ tissulaire ne changeait pas après administration d'acide domoïque ou pendant les intervalles d'activités paroxystiques ou -d'état de mal épileptique-. Les souris non ventilées ont présenté des périodes de suppression à l'EEG accompagnées par des diminutions des taux des métaboliques phosphatés de haute énergie et de $\mathrm{PH}$, correspondant à une suppression respiratoire épisodique pendant les périodes de pontes. Chez tous les animaux, l'état de mal épileptique était suivi par une diminution prononcée dans l'amplitude de l'EEG, qui s'est rapidement transformée en un silence isoélectrique. Les spectres IRM ${ }^{31} \mathrm{P}$ obtenus après ce phénomène indiquaient un déficit énergétique total et une acidose tissulaire. Dans un groupe séparé de souris ventilées $(n=4)$, l'état de mal induit par acide domoïque était accompagné initialement par une augmentation de la pression artérielle moyenne, qui est revenue lentement au niveau basal. Le silence isoélectrique était accompagné par une diminution de la pression artéielle moyenne à $75 \pm \mathrm{mm} \mathrm{Hg}$. Ces expériences suggèrent que les crises induitent par acide domoïque ne s'accompagnent pas d'une augmentation de la demande en substrat qui excèderait les disponibilités.

(P. Genton, Marseille)

\section{RESUMEN}

Utilizando la electroencefalografía continua (EEG) y la espectroscopia por Resonancia Magnética ${ }^{31} \mathrm{P}$ (NMR) se ha estudiado en ratones el efecto de la actividad convulsiva inducida por el ácido domoico sobre el metabolismo energético y sobre el pH cerebral. Los ratones se dividieron en ventilados $(n=6)$ y noventilados $(n=7)$. El EEG basal mostró una amplitud de $0.1 \mathrm{mV}$ con frencuencias de $>30$ y $4.5 \mathrm{~Hz}$. Tras la inyección intraperitoneal de ácido domoico $(6 \mathrm{mg} / \mathrm{kg})$ se observó un incremento de la frecuencia de las puntas electrográficas que progresó hasta una amplitud mayor $(0.1-0.8 \mathrm{mV})$ y alcanzer actividad epiléptica (status epilepticus). En los ratones ventilados los espectros de ${ }^{31} \mathrm{P}$ NMR mostraron que los niveles de los fosfatos de alta energía y el $\mathrm{pH}$ tisular no cambiaron tras la administración de ácido domóico o durante los intervalos de las puntas o el status epilepticus. Los ratones no-ventilados mostraron periodos de supresion en el EEG asociados a una reducción de los niveles de los metabolitos de los fosfatos de alta energía y del pH que correspondían a una supresión respiratoria episódica durante los intervalos de las puntas. En todos los animales el status epilepticus se siguió de una marcada reducción de la amplitud en el EEG que rápidamente progresó a un silencio isoeléctrico. El espectro ${ }^{31} \mathrm{P}$ NMR obtenido después de este silencio indicaba un fallo total de energia y acidosis tisular. Un grupo distinto de ratones ventilados $(n=4)$ el status epilepticus inducido por el ácido domoico se asoció inicialmente a un incremento de la presión arterial media que descendió lentamente a los niveles bassales. El silencio isoeléctrico se acompañó de una reducción de la presión arterial media hasta $75 \pm 8 \mathrm{~mm} \mathrm{Hg}$. Estos experimentos sugieren que los ataques inducidos por el ácido domóico no se asocían a un incremento en la demanda de sustratos que exceda la suplencia.

(A. Portera-Sánchez, Madrid) 